International Journal of Agriculture, Environment and Bioresearch

Vol. 5, No. 01; 2020

ISSN: $2456-8643$

\title{
EFFECT OF TILLAGE PRACTICE ON GROWTH AND YIELD OF MAIZE IN UGANDA
}

\author{
Bongomin $L^{*}$ \\ Uganda Martyrs`University Nkozi, P.O Box 5498, Kampala, Uganda, \\ Acipa A. \\ Ngetta Zonal Agricultural Research and Development Institute, P.O Box 52, Lira, Uganda \\ Wamani S. \\ Uganda Martyrs` University Nkozi, P.O Box 5498, Kampala, Uganda, National Crops Resources Research Institute, \\ P.O Box 7084, Kampala, Uganda \\ Dr Sseremba G. \\ Uganda Martyrs` University Nkozi, P.O Box 5498, Kampala, Uganda
}

https://doi.org/10.35410/IJAEB.2020.5468

\begin{abstract}
The study aimed at evaluating the effect of tillage practice on vegetative growth and yields of maize and was guided by the following objectives;i) to evaluate the effect of tillage practice on vegetative growth of maize, and ii) evaluate the effect of tillage practice on maize yield. The experiment was conducted in two locations; one at the Zonal Agricultural Research and Development institute in Ngetta Sub County, Lira district and another one in Njeru Town council in Buikwe district. Maize varieties Longe $10 \mathrm{H}$ and Longe 5 were used in this experiment. The experiment was arranged in a factorial design with 2 tillage practices (conventional tillage, CT and minimum tillage, MT) as the main factors and 2 maize varieties (Longe $10 \mathrm{H}$ and Longe $5 \mathrm{H}$ ) as the levels. The results showed that there was significant difference in plant height, stem girth and leaf width between the two tillage methods.Conventional tillage practice resulted in higher maize grain yield (figure 8)than minimum tillage (figure 8) although the yield difference between the two practices was insignificant. If farmers are to adopt minimum tillage practice in Uganda, they are advised invest in herbicides in order to control the weed.
\end{abstract}

Keywords: Conventional tillage, minimum tillage, vegetative growth, yield, maize.

\section{INTRODUCTION}

Tillage has been recognized as a cause of intense landscape modification and as a major source of soil erosion and redistribution along the hill slopes (Torri et al., 2002). Despite profound evidence of soil translocation processes, it was only in the 1990's that systematic research on this topic began (Van Oost et al., 2006).Conservation tillage is the use of agricultural practices that have minimal soil disturbances (Sarker et al., 2012).Conservation agriculture is defined as a farming system where there is a permanent soil cover, minimal soil disturbance and where crop rotation is practiced (Act et al., 2003). It also includes the use cover crops as a soil amelioration measure (Mariki, 2003). Small resource poor farmers who have adopted conservation tillage methods cite the reduction in labour inputs and drudgery as major drivers for adoption (Saturnino 
et al., 2002). Conservation agriculture is also known to improve crop yields, reduce soil erosion, soil fertility improvement, and reduces labour requirements (Giller et al., 2009).

Several types of conservation tillage such as minimum tillage, incomplete tillage, reduced tillage, and no tillage, etc. are practiced across the world. According to data gathered by the Conservation Technology Information Center (Anon., 2004), about $40.7 \%$ of total crop land on 45.44 million hectares was under conservation tillage system. Of that, no tillage was used on about $23.6 \%$ of land in the United States. Generally reduced or no tillage provides minimum disturbance of the soil and leaves the surface covered with crop residues. The crop residues are not absolutely mixed and most or all of them remain on the top of soil surface rather being ploughed into the soil. They maintain a constant cover of organic material on the surface, which retains water and minimizes runoff, reduces erosion and sedimentation and improves water quality.

In improving soil condition, tillage is a key factor and plays a significant role in improving maize growth and grain yield. A compacted soil layer, because of its high strength and low porosity, confines the crop roots in the top layer and reduces the volume of soil that can be explored by the plants for nutrients and water (Lipiec etal., 2003). Due to compaction, availability of soil nutrients to roots is also reduced, which results in decreased shoot number.

Maize (Zea mays L.) is one of the most important cereal crops in Uganda and it ranks second in cultivated area and production after rice. It has greater nutritional value as it contains about $72 \%$ starch, $10 \%$ protein, $4.8 \%$ oil, $8.5 \%$ fiber, $3 \%$ sugar and $17 \%$ ash (Karunatilakeet al., 2000). Due to higher yield potential, short growing period, high value for food, forage and feed for livestock, poultry and a cheaper source of raw material for agro-based industry, it is increasingly gaining an important position in the cropping system (Karunatilakeet al., 2000).

It belongs to Gramineaefamily of plant kingdom. As maize is the highest yielding cereal crop in the world, it is of considerable substance for countries like Uganda, where rapidly increasing population has already short of existing food supplies. Maize accounts for $4.8 \%$ of the total cropped area and $3.5 \%$ of the value of agricultural output. In Uganda, the North, Eastern and Central are the major producers of maize. Its importance is apparent in daily life food stuff as it used as edible oil and high valued food for human beings, feed for livestock and poultry and raw material for various agro-based industries (Khurshidet al., 2006).

There is inadequate information on the effect of tillage methods on maize growth and yield in Uganda. This study was therefore a necessary step taken to bridge the gap in information on effect of tillage on growth, yield and yield components of Maize. Maize has become an important staple food in Uganda with very high competing demands between human consumption and other industrial uses such as feed production for livestock consumption. There is need therefore to increase the production of maize to meet the increasing demand. It therefore becomes imperative that the study focuses on theeffect of tillage practice on the growth and yield of the crop in a bid to enhance sustainable production of maize and ensure food security in the country using Lira and Buikwe districts as case studies. 
Vol. 5, No. 01; 2020

ISSN: $2456-8643$

\section{MATERIALS AND METHODS}

\subsection{Experimental Sites}

Two field trials were established in Uganda in the districts of Buikwe (Njeru) and Lira (Ngetta Zonal Agricultural Research and Development Institute). These sites represent two maize growing agro ecological zones of Uganda, namely Lake Victoria Crescent and Northwestern Savanah Grassland respectively.

Lake Victoria Crescent is characterized by sandy clay alluvial soils with moist semi-deciduous forest, savannas, and swamps. The area receives rainfall ranging from $1750 \mathrm{~mm}$ to $2000 \mathrm{~mm}$ with bimodal rains comprising of April to May for the first ones and October to December for the second rains. Temperature ranges from $11^{\circ} \mathrm{c}$ to $33^{\circ} \mathrm{c}$. Climate is warm and wet with relatively high humidity and averaging an altitude of $1134 \mathrm{~m}$ above sea level. Northwestern Savanah Grassland is comprised of ferruginous sandy loam soils with intermediate savanna grassland and scattered trees. The rainfall received ranges averagely from $1340 \mathrm{~mm}-1371 \mathrm{~mm}$ with bimodal rains followed by a dry spell for about 5 months. Temperature and altitude range from $15-25^{\circ} \mathrm{C}$ and $951-1341 \mathrm{~m}$ above sea level respectively (Sam Wamani etal Mildred Ochwo-Semakula). These two agro ecological zones were selected for the study based on their distinct ecological features or conditions and the big number of farmers growing maize

\subsection{Source and description of Maize variety}

Two maize varieties were used for the study namely Longe 5 and Longe $10 \mathrm{H}$. These two varieties were selected based on their distinct characteristics.Longe 5 is a drought tolerant variety, sweet at green maturity, resistant to grey leaf spot and maize streak virus. It also has a good cob size and it's suitable for low and mid altitude areas like Buikwe and Lira district.On the other hand, Longe $10 \mathrm{H}$ is high yielding, ideal for mid altitude, bred with good drought and storage pest resistance. The seed was acquired from Naseco Seed Company in Uganda.

\subsection{Experimental Design and Management}

The experiment was arranged in a factorial design with 2 tillage practices (conventional tillage, $\mathrm{CT}$ and minimum tillage, MT) as the main factors and 2 maize varieties (Longe $10 \mathrm{H}$ and Longe 5 ) as the levels. It was replicated three times. Plot sizes were $5 \mathrm{~m} \times 5 \mathrm{~m}$ with inter-plot spacing of $1 \mathrm{~m}$. For No tillage, planting basins were dug after slashing at $0.6 \mathrm{~m} \times 0.9 \mathrm{~m}$ spacing using a hand hoe and each basin was measure $0.15 \mathrm{~m}$ (length) x $0.15 \mathrm{~m}$ (width) x $0.15 \mathrm{~m}$ (depth). Conventional tillage was done using a hand hoe. The first trial was planted in second season of September, 2017 while the second one was planted in the first season of March, 2018. It was done at $0.75 \mathrm{~m} \mathrm{x}$ $0.25 \mathrm{~m}$ spacing with 4 maize seeds per hole for planting basins. Thinning was done to 2 plants per basin for planting basins and 2 plants for conventional tillage.

\subsection{Field data collection}

Data was collected every forth night. The first data was picked after two weeks from time of planting. Data was collected on plant height, leaf width, stem girth, leaf length, number of leaves every fourth night and maize yield after harvest. 


\subsubsection{Data collection procedure}

10 plants were randomly selected from each of the plots. Each plant was observed and measurements done every after two weeks. Leaf length, leaf width, plant height, stem girth, was measured using a string and the values read from a ruler. The maize cobs were harvested after 15 weeks and weighed on a weighing scale. The cobs from each of the plots were also threshed and weighed separately. 100 seed weight was also weighed per plot and the data captured(Kayode, J. and Ademiluyi, B. (2004).

\subsection{Data Analysis}

The data set for maize vegetative growth (leaf length, leaf girth, plant height, stem girth, leaf width) and maize yield were summarized and mean values obtained. ANOVA was done using GenStat version 12 statistical package to establish the effect of different tillage practices on maize.

\section{RESULTS}

3.1 Effect of tillage practice on vegetative growth of maize

\subsubsection{Plant height}

Table 1: Mean plant height $(\mathrm{cm})$ of two maize varieties under two contrasting tillage practices

\begin{tabular}{|c|c|c|c|c|}
\hline \multirow[b]{2}{*}{ Stage (WAP) } & \multicolumn{2}{|c|}{ Longe $10 \mathrm{H}$} & \multicolumn{2}{|l|}{ Longe 5} \\
\hline & CT & MT & CT & MT \\
\hline 2 & 23.83 & 18.53 & 17.76 & 23.27 \\
\hline 4 & 41.81 & 39.81 & 50.47 & 57.36 \\
\hline 6 & 119.78 & 131.66 & 110.9 & 126.86 \\
\hline 8 & 125.08 & 136.85 & 150.32 & 138.31 \\
\hline Mean & 77.625 & 81.7125 & 82.3625 & 86.45 \\
\hline s.e.d & 2.614 & 1.848 & 1.848 & 2.614 \\
\hline 1.s.d $(\alpha=5 \%)$ & 5.127 & 3.625 & 3.625 & 5.127 \\
\hline
\end{tabular}




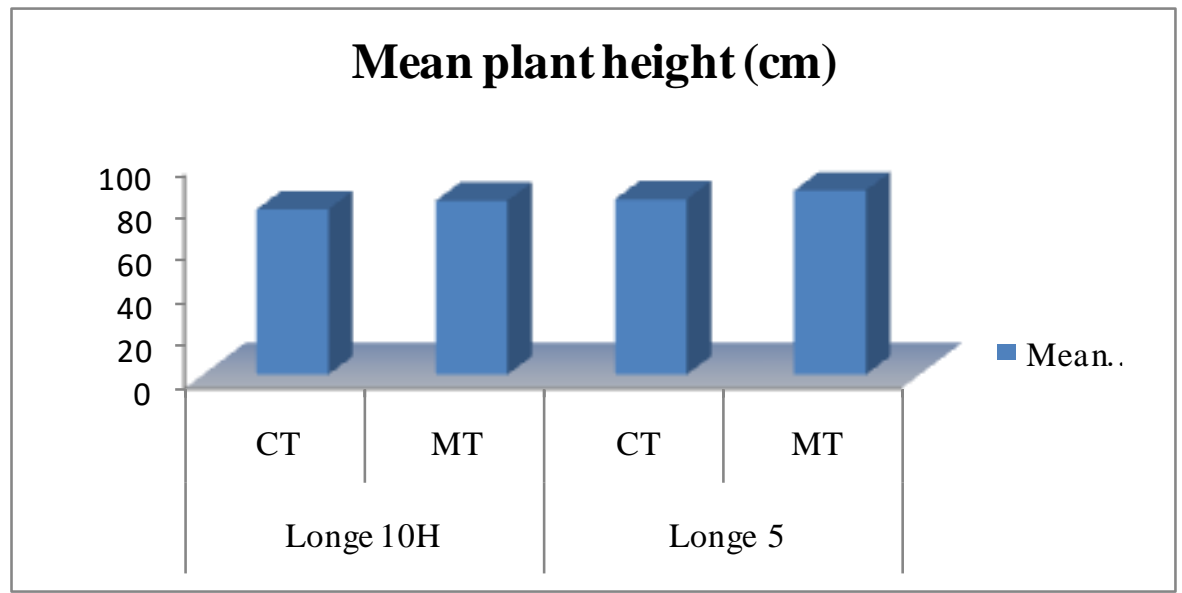

Figure 1: Mean plant height of two maize varieties under two tillage practices

3.1.2 Number of leaves per plant

Table 2: Mean Number of leaves of two maize varieties under two contrasting tillage practices

\begin{tabular}{|lllll|}
\hline \multirow{2}{*}{ Stage (WAP) } & Longe 10H & \multicolumn{3}{c|}{ Longe 5 } \\
\cline { 2 - 5 } & CT & MT & CT & MT \\
\hline 2 & 5.182 & 4.768 & 4.902 & 5.032 \\
6 & 8.265 & 7.468 & 8.177 & 8.682 \\
8 & 11.982 & 12.91 & 12.327 & 12.407 \\
Mean & 13.298 & 14.043 & 13.352 & 13.098 \\
s.e.d & 9.68175 & 9.79725 & 9.6895 & 9.80475 \\
1.s.d $(\alpha=5 \%)$ & 0.1834 & 0.1297 & 0.1297 & 0.1834 \\
& 0.3598 & 0.2544 & 0.2544 & 0.3598 \\
\hline
\end{tabular}

\subsubsection{Stem Girth}


International Journal of Agriculture, Environment and Bioresearch

Vol. 5, No. 01; 2020

ISSN: $2456-8643$

Table 3: Mean Stem Girth $(\mathrm{cm})$ of maize under two contrasting tillage practices

\begin{tabular}{|c|c|c|c|c|}
\hline \multirow[b]{2}{*}{ Stage (WAP) } & \multicolumn{2}{|c|}{ Longe $10 \mathrm{H}$} & \multicolumn{2}{|l|}{ Longe 5} \\
\hline & CT & MT & $\mathrm{CT}$ & MT \\
\hline 2 & 1.481 & 1.086 & 1.373 & 1.327 \\
\hline 4 & 2.946 & 2.27 & 2.603 & 2.525 \\
\hline 6 & 6.577 & 6.695 & 6.775 & 6.21 \\
\hline 8 & 6.941 & 6.949 & 6.826 & 6.57 \\
\hline Mean & 4.48625 & 4.25 & 4.39425 & 4.158 \\
\hline s.e.d & 0.1669 & 0.118 & 0.118 & 0.1669 \\
\hline 1.s.d $(\alpha=5 \%)$ & 0.3274 & 0.2315 & 0.2315 & 0.3274 \\
\hline
\end{tabular}

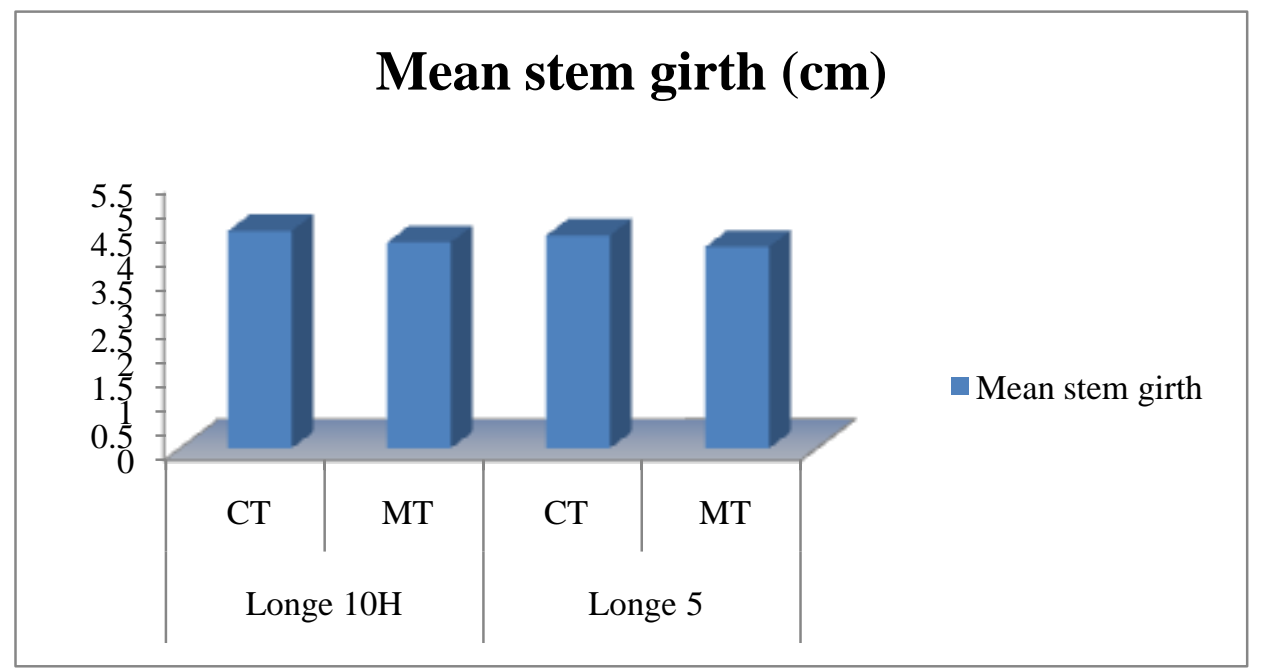

Figure 2: Mean stem girth of two maize varieties under two tillage practices

\subsubsection{Leaf Length}


International Journal of Agriculture, Environment and Bioresearch

Vol. 5, No. 01; 2020

ISSN: $2456-8643$

Table 4: Mean Leaf length $(\mathrm{cm})$ of maize under two contrasting tillage practices

\begin{tabular}{|c|c|c|c|c|}
\hline \multirow[b]{2}{*}{ Stage (WAP) } & \multicolumn{2}{|c|}{ Longe $10 \mathrm{H}$} & \multicolumn{2}{|l|}{ Longe 5} \\
\hline & CT & MT & CT & MT \\
\hline 2 & 21.8 & 17.12 & 10.75 & 9.47 \\
\hline 4 & 38.39 & 37.13 & 39.82 & 43.81 \\
\hline 6 & 65.46 & 68.43 & 73.14 & 72.33 \\
\hline 8 & 70.83 & 73.45 & 76.38 & 74.13 \\
\hline Mean & 49.12 & 49.0325 & 50.0225 & 49.935 \\
\hline s.e.d & 1.314 & 0.929 & 0.929 & 1.314 \\
\hline 1.s.d $(\alpha=5 \%)$ & 2.577 & 1.823 & 1.823 & 2.577 \\
\hline
\end{tabular}

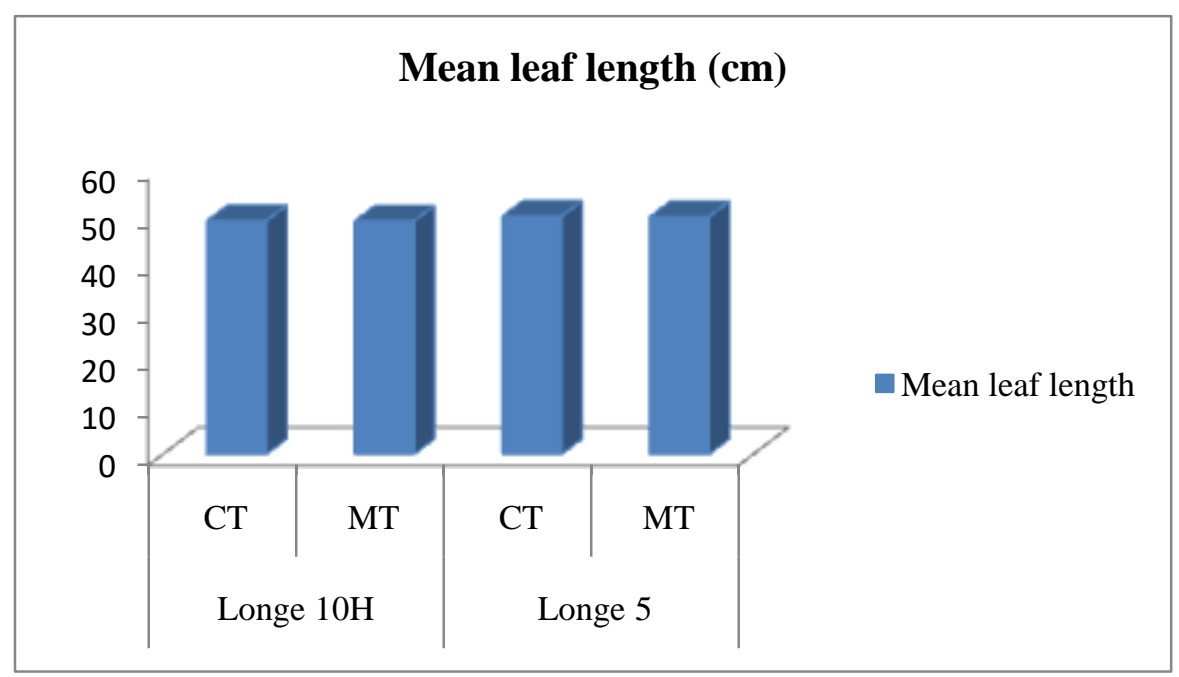

Figure 3: Mean leaf length of two maize varieties under two tillage practices 3.1.5 Leaf width 
International Journal of Agriculture, Environment and Bioresearch

Vol. 5, No. 01; 2020

ISSN: $2456-8643$

Table 5: Mean Leaf width $(\mathrm{cm})$ of maize under two contrasting tillage practices

\begin{tabular}{|c|c|c|c|c|}
\hline \multirow[b]{2}{*}{ Stage (WAP) } & \multicolumn{2}{|c|}{ Longe $10 \mathrm{H}$} & \multicolumn{2}{|l|}{ Longe 5} \\
\hline & $\mathrm{CT}$ & MT & CT & MT \\
\hline 2 & 2.191 & 1.976 & 1.691 & 1.438 \\
\hline 4 & 4.504 & 3.57 & 4.846 & 4.569 \\
\hline 6 & 8.614 & 8.556 & 8.999 & 8.658 \\
\hline 8 & 9.071 & 8.971 & 9.237 & 8.8 \\
\hline Mean & 6.095 & 5.76825 & 6.19325 & 5.86625 \\
\hline s.e.d & 0.1718 & 0.1215 & 0.1215 & 0.1718 \\
\hline 1.s.d $(\alpha=5 \%)$ & 0.3369 & 0.2382 & 0.2382 & 0.3369 \\
\hline
\end{tabular}

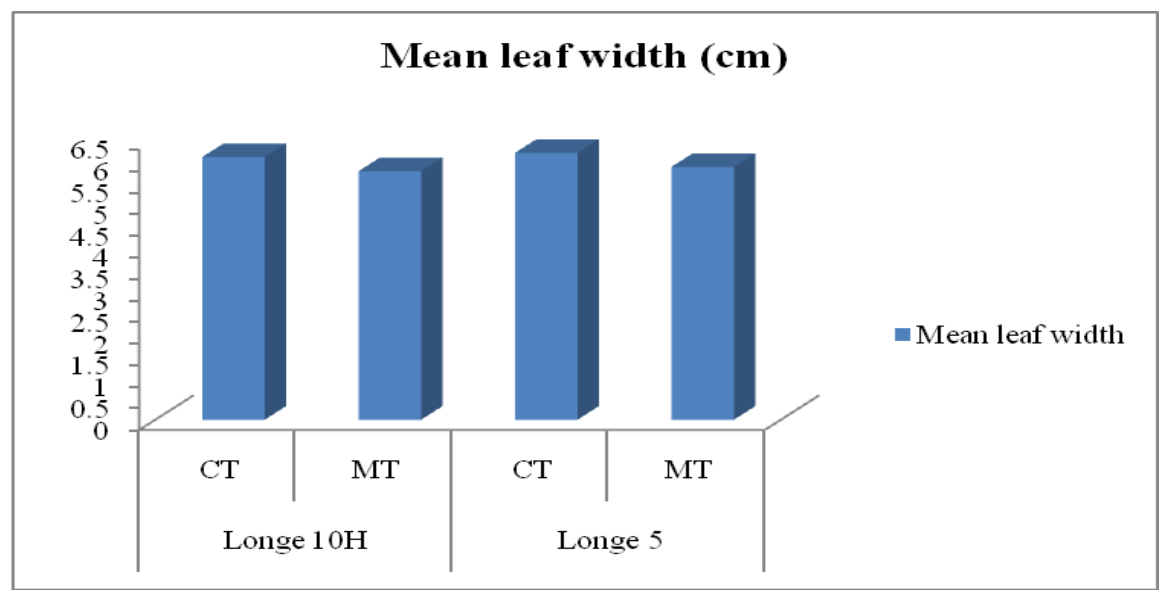

Figure 4: Mean leaf width of two maize varieties under two tillage practices

3.2Effect of tillage practice on yield of maize

3.2.1 100 seed weight 


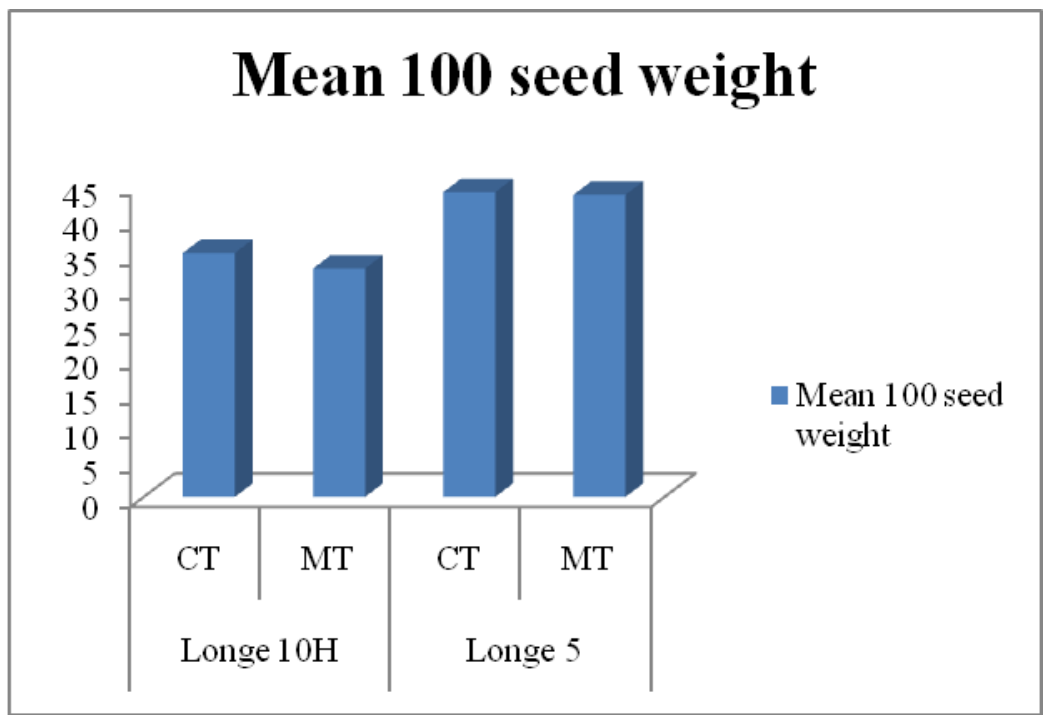

Figure 5: Mean 100 seed weight of two maize varieties under two contrasting tillage practices

\subsubsection{Grain moisture content}

Table 6: Mean Percentage MC of maize grain under two contrasting tillage practices

\begin{tabular}{|c|c|c|c|c|}
\hline \multirow[b]{2}{*}{ Season } & \multicolumn{2}{|c|}{ Longe $10 \mathrm{H}$} & \multicolumn{2}{|c|}{ Longe 5} \\
\hline & CT & MT & $\mathrm{CT}$ & MT \\
\hline 2017B & 13.4 & 12.833 & 11.55 & 11.267 \\
\hline $2018 \mathrm{~A}$ & 14.05 & 13.983 & 13.133 & 13.4 \\
\hline Mean & 13.725 & 13.408 & 12.3415 & 12.3335 \\
\hline s.e.d & 0.2621 & 0.2621 & 0.3707 & 0.3707 \\
\hline 1.s.d $(\alpha=5 \%)$ & 0.534 & 0.534 & 0.7551 & 0.7551 \\
\hline
\end{tabular}




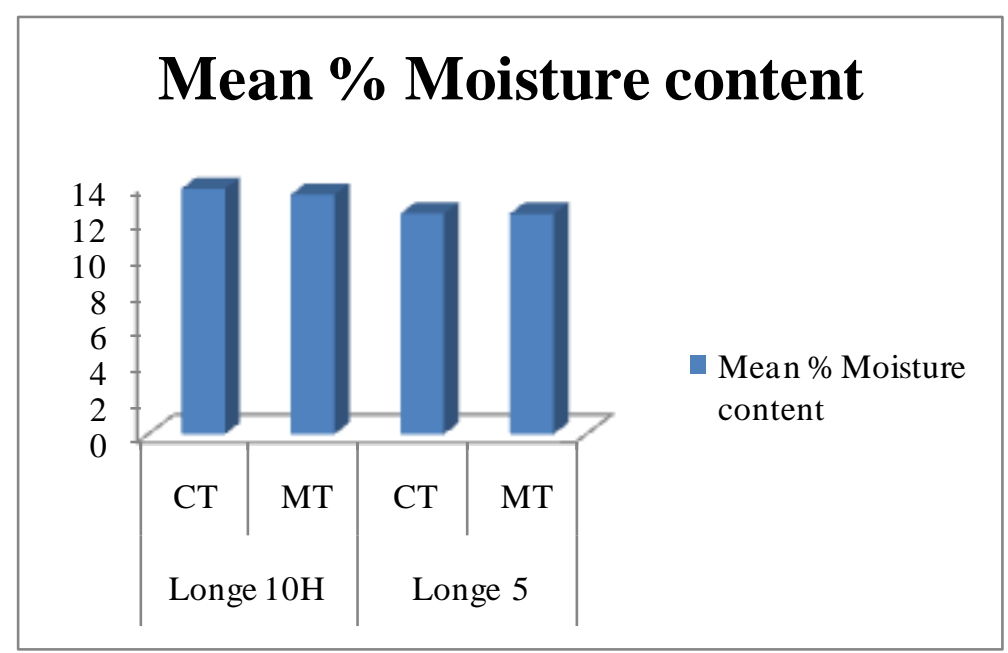

Figure 6: Mean percentage moisture content of two maize varieties under two contrasting tillage practices

\subsubsection{Grain yield per Hectare}

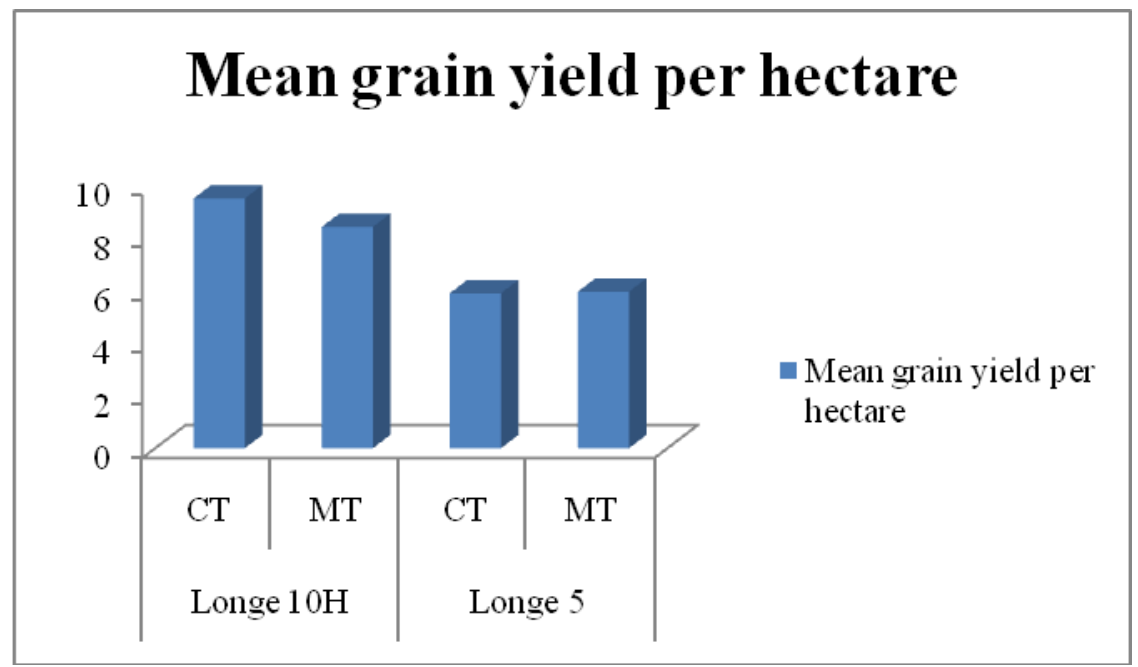

Figure 5: Mean grain yield of maize per hectare under two contrasting tillage practices

\section{DISCUSSIONS}

\subsection{Plant height}

There was significant difference in plant height between the different tillage treatments except at 8 weeks after planting. The highest mean height was located in the conventional tillage plots with Longe 5 (Table 1) variety while the lowest mean height was found in the conventional Tillage 
plots for Longe 10H (Table 1). These results are similar to that of Kayode and Ademiluyi (2004) who observed the least mean height was registered in the No Tillage plots in comparison with that in the tilled plots in Southwestern Nigeria. Khurshidet al. (2006) also reported taller plants in conventional tillage plots compared to theminimum tillage plots in Faisalabad, Pakistan. In contrast, Ojeniyi and Adekayode (1999) reported taller maize plants in the No Tillage plots compared to conventional plots at Akure, located in the rainforest zone of Nigeria. Also, plant height varied significantly with time and variety. Minimum tillage recorded the highest mean heights for week two, four, six and eight on variety Longe 5 (Figure 1).

\subsection{Number of leaves}

Leaves are the site of photosynthetic activities of crops through which biomass are produced, partitioned among various parts of crops and stored for crop productivity (Asareet al., 2011). There was no significant effect of tillage practices on maize number of leaves per plant $(\mathrm{P}=0.05)$. At 8 weeks after planting, the no tillage plots produced the highest number of leaves (9.7) per plant compared to the conventional tillage plots (9.6). Also Longe 5 recorded the highest mean number of leaves 9.7 compared to Longe $10 \mathrm{H} 9.6$.

\subsection{Stem girth}

Stem girth is an expression of vegetative growth (Squire, 1990). At 8 weeks after planting there was significant difference in stem girth between Minimum Tillage and Conventional Tillage. Overall, the highestmean maize plant stem girth was observed in the Conventional Tillage plots. The lowest stem girth was registered in the No Tillage plots. Similar results were obtained by Aikins and Afuakwa (2010) experiment on different tillage practices on maize performance under rainfed conditions. More to that, stem girth differed significantly with the location $\mathrm{P}<0.05$

\subsection{Leaf length}

There was no significant difference in mean leaf length between the two tillage practices ( $p .853)$. The mean leaf length for Conventional Tillage and Minimum Tillage was $49.5 \mathrm{~cm}$ and $49.4 \mathrm{~cm}$ respectively. The result also showed that there was a significant difference in mean leaf length between the two sites (Lira and Buikwe) $(p<0.05)$.

\subsection{Leaf width}

Leaf width is important for photosynthesis and yield. Leaf width is important for crop light interception and therefore has a large influence on crop yield (Dwyer and Stewart, 1986).There was a significant effect of tillage practices on leaf width $(\mathrm{P}<0.05)$ (Table 5). At 8 weeks after planting, Conventional Tillage treatment produced the highest leaf width $(6.1 \mathrm{~cm})$ compared to Minimum Tillage $(5.8 \mathrm{~cm})$.The minimum tillage plots produced the smallest leaf width.

\subsection{0 seed weight}

Tillage had a significant effect on varietal seed weight in this study $(\mathrm{P}<0.05)$. Conventional tillage had the highest seed weight when compared to minimum tillage. This could be because in conventional practice, the maize plants were not affected by weeds at the early stages hence the plant was able to intake enough nutrients for growth and seed development. This result, agrees 
with earlier reports that found taller maize plants in no tillage plots under ferric luvisol in the rain forest zone of Nigeria (Ojeniyi\&Adekayode, 2009), but in contrast with other reports that observed that taller plants in tilled plots (Aikins\&Afuakwa, 2010). The higher maize weight in conventional tillage compared to minimum tilled may be attributed to better aeration and adequate moisture or differences in soil structure since the soil was tilled before planting was done. This method also helped to reduce weed growth and improved availability of nutrients for plant growth. (Ogban, et al. 2008)

\subsection{Grain moisture content}

Conventional tillage plotsregistered higher maize grain moisture (13\%) than the minimum tillage plots $(12.8 \%)$ though they did not differ significantly. (Table 6).Please discuss why you think the trend was like that and then add literature. Polthanee\&Wannapat (2000) confirmed this trend when they reported slightly higher grain moisture in conventional tillage than minimum tillage.

\subsection{Grain yield per hectare}

Conventional tillage recorded higher total dry matter yield (7.6MT) than minimum tillage (7.1MT)though the difference was insignificant. Please discuss your reason for the difference in yield before you quote literature. This observation is in agreement with Aikins\&Afuakwa( 2010) experimenton the different tillage practices on maize performance under rainfed conditions in Nigeria, which recorded higher dry matter in conventional tillage plot compared to minimum tillage. Contrary to that, Shao et al. (2016) in China manifested that 1000-grain weight was significantly higher in conservation tilled plots.

\section{CONCLUSION}

This study revealed that there was a significant difference in plant height, stem girth and leaf width of maize between the two tillage practices (conventional and minimum). Conventional tillage practice resulted in higher maize grain yield than minimum tillage although the yield difference between the two practices was insignificant. Despite minimum tillage having less labor demand at land preparation, a farmer is advised to invest in herbicides in order to control the weeds if this tillage practice is to be adopted in Uganda.

\section{Acknowledgement}

This study was funded by ACALISE project of Uganda Martyrs`University, Nkozi.

\section{REFERENCES}

1. Adu, S.V., 1992. Soils of the Kumasi region, Ashanti region, Ghana. Soil Research Institute.

2. Aikins, S.H.M. and Afuakwa, J.J., 2010. Effect of four different tillage practices on cowpea performance. World Journal of Agricultural Sciences, 6(6), pp.644-651.

3. Agbede, T., Ojeniyi, S. and Adekayode, F., 2009. Effect of Tillage on Soil Properties and Yield of Sorghum (Sorghum Bicolor (L.) Moench) in Southwest Nigeria. Nigerian Journal of Soil Science, 19(2). 
4. Asare, P.A., Galyuon, I.K.A., Sarfo, J.K. and Tetteh, J.P., 2011. Morphological and molecular based diversity studies of some cassava (ManihotesculentaCrantz) germplasm in Ghana. African Journal of Biotechnology, 10(63), pp.13900-13908.

5. Dwyer, L.M. and Stewart, D.W., 1986. Leaf Area Development in Field-Grown Maize 1. Agronomy Journal, 78(2), pp.334-343.

6. Giller, K.E., Witter, E., Corbeels, M. and Tittonell, P., 2009. Conservation agriculture and smallholder farming in Africa: the heretics' view. Field crops research, 114(1), pp.23-34.

7. Karunatilake, U., Van Es, H.M. and Schindelbeck, R.R., 2000. Soil and maize response to plow and no-tillage after alfalfa-to-maize conversion on a clay loam soil in New York. Soil and Tillage Research, 55(1-2), pp.31-42.

8. Kayode, J. and Ademiluyi, B., 2004. Effect of tillage methods on weed control and maize performance in Southwestern Nigeria location. Journal of sustainable agriculture, 23(3), pp.39-45.

9. Khurshid, K.A.S.H.I.F., Iqbal, M.U.H.A.M.M.A.D., Arif, M.S. and Nawaz, A.L.L.A.H., 2006. Effect of tillage and mulch on soil physical properties and growth of maize. International Journal of Agriculture and Biology, 8(5), pp.593-596.

10. Lipiec, J. and Hatano, R., 2003. Quantification of compaction effects on soil physical properties and crop growth. Geoderma, 116(1-2), pp.107-136.

11. Mariki, W., 2003. The Impact of Conservation Tillage and Cover Crops on Soil Fertility and Crop Production in Karatu and Hanang Districts of Northern Tanzania. TFSC Technical Report 1999-2003. Arusha: TFSC/GTZ.

12. Ojeniyi, S.O. and Adekayode, F.O., 1999. Soil conditions and cowpea and maize yield produced by tillage methods in the rainforest zone of Nigeria. Soil and Tillage Research, 51(1-2), pp.161-164.

13. Polthanee, A. and Wannapat, S., 2000. Tillage and mulching effect on growth and yield of cowpea grown following rice in the post-monsoon season of northeastern Thailand. Kasetsart Journal of Natural Science, 34(2), pp.197-204.

14. Saturnino, H.M., Landers, J.N. and Campos, E., 2002. The environment and zero tillage. CEP, 70760, p.533.

15. Squire, G.R., 1990. The physiology of tropical crop production. CAB International.

16. Torri, D., Borselli, L., Calzolari, C., Yañez, M. and Salvador-Sanchis, M.P., 2002. Soil erosion, land use, soil quality and soil functions: effects of erosion. Man and soil at the third millennium, pp.131-148.

17. Van Oost, K., Govers, G., De Alba, S. and Quine, T.A., 2006. Tillage erosion: a review of controlling factors and implications for soil quality. Progress in Physical Geography, 30(4), pp.443-466. 